\title{
UN'SECRETARIES-GENERAL INITIATIVES IN RESPONSE TO THE CHALLENGES OF THE INTERNATIONAL SECURITY ENVIRONMENT
}

Nicușor COJAN*

Throughout its history, the United Nations (UN) has developed and tried to adapt in order to be able to respond to the challenges of the international security environment. Contemporary society is composed of a complex ofeconomic, political, cultural, religious entities, etc., in a continuous evolution or transformation, which also generate ever new challenges to the very existence of human existence. Against this background, we have considered it useful to review some UN initiatives, key documents and policies, from the beginning until nowadays, in order to address as many of the challenges as possible in the international security environment, in an attempt to create a better world, demonstrating the important role of SecretariesGeneral in the evolution and development of the organization.

Keywords: global challenges; security environment; UN initiatives; UN Secretary-General; 2030 Agenda.

\section{Challenges to Global Security}

The beginning of the $21^{\text {st }}$ century finds mankind in a state of severe crisis, global society is facing a number of new challenges, on whose resolution, scientists believe, future progress and even the survival will depend.

* Nicușor COJAN is a PhD Candidate within the Doctoral School of "Carol I" National Defence University, Bucharest, Romania.E-mail: nicusor.cojan@yahoo.com 
Research is based on the assessments and considerations related to global challenges, also the analyses and reports of renowned researchers, analysts and specialists in the field of research centers or international institutes that try to sound an alarm signal to the critical situation in which we find ourselves as a civilization. The development of contemporary human society has not been done on a sustainable basis, the destruction of the natural environment, conflicts over resources, overpopulation, fierce human competition or exacerbated individualism, maintaining the arms race and modern slavery are all manifestations that do not belong to modern civilization.

The identification of global challenges is the result of ongoing research, and of studies such as "Delphi", reports of the World Economic Forum (WEF) or the Organization for Economic Co-operation and Development (OECD), summits, conferences and interviews with experts from around the world. Thus, among the global challenges discussed in these forums and meetings, the most debated challenges included were: poverty, corruption, unemployment, economic globalization, migration, human rights, terrorism, armed conflict, climate change, environmental pollution, epidemics, and religious conflicts.

Living in an increasingly globalized society, we believe that analyzing these challenges in an intercorrelated way would be the most effective, because conducting a separate study, focusing exclusively on each challenge, may not always lead to the identification of all causes. Globally, the UN estimated that 15 security challenges ${ }^{2}$ can be highlighted in this way:

1. achieving sustainable development for all involved, as we tackle global climate change;

2. ensuring clean water for all the world's population, without conflicts occurring in the world;

3. balancing population growth with declining resources;

4. authoritarian regimes can make room for genuine democracy;

5. optimizing decision-making by integrating improved global forecast during an unprecedented accelerated change;

6. how global convergence of information and communication technologies for all can work;

7. encouraging ethical market economies to help reduce the gap between rich and poor;

8. reducing the threat of new diseases, their recurrence and immune

\footnotetext{
${ }^{1}$ A.N.: The Real-Time Delphi is a relatively new and effective method for collecting and synthesizing expert opinions. The original Delphi technique was developed by RAND Corporation in the late 1950s.

${ }^{2}$ The Millennium Project, Global Futures Studies \& research, URL: http://www.millennium-project. $\mathrm{org} / \mathrm{projects/challenges/,} \mathrm{accessed} \mathrm{on} \mathrm{12.05.2021.}$
} 
microorganisms;

9. how education can make humanity smarter, more informed and wiser enough to meet global challenges;

10. reducing ethnic conflicts, terrorism and the use of weapons of mass destruction through common values and new security strategies;

11. how the changing status of women can contribute to improving the human condition;

12. counteracting transnational organized crime networks so that they do not become stronger and more sophisticated global enterprises;

13. safely and efficiently meet growing energy demands;

14. accelerating scientific and technological discoveries;

15. ethical considerations to be incorporated into global decisions.

All of these global challenges take place in a complex interconnected system, with a seemingly unimportant event in a particular region of the globe causing instability in another remote area of the world.

From our standpoint, following the study of a significant number of bibliographic reference sources, the global challenges, with major impact, that we face and that the society will probably face in the future, we appreciate that they are the following: climate change; extreme poverty and inequality; economic and financial crises; food crisis; water shortage; energy security; migration; population growth and demographic change; urbanization; pandemics and infectious diseases.

Studies and analyzes of the various institutes, have identified many more challenges that can affect the future of humanity for which urgent UN solutions are needed.

In the first four decades of its existence during the Cold War, the blocking of some draft Security Council decisions by some Member States led to many dysfunctions in the organization's activity. Despite the ideological and power conflicts between the two political-military blocs ${ }^{3}$, which influenced the debates and negotiations in all organization's forums, UN has continued to play its role as a key international body in conflict prevention, international crisis management, but also promotion and defence of individual rights and freedoms.

The United Nations has managed to improve the lives of millions of people and prevent a series of crises in its 76 years of existence. It is worth mentioning the UN Charter on the Rights of the Child or the fight against diseases such as AIDS and malaria. The UN has also achieved notable successes in terms of the millennium goals. According to official data, the number of people suffering from

\footnotetext{
${ }^{3}$ A.N.: In the Cold War, two groups of states clashed with very different ideologies and political systems. The USSR and its allies, the "Eastern Bloc" represented at the politico-military level by the Warsaw Pact and, respectively, the USA and its allies - the "Western Bloc", represented by NATO.
} 
global hunger ${ }^{4}$ has been halved, and infant mortality has been reduced by $60 \%$ from 1990 to the present day, according to the report presented by UNCEF in $2020^{5}$. These are impressive achievements, all the more so as the UN has meanwhile set the goal of sustainable world development. This is only possible through a mixture of economic development, social progress and care for the environment.

As the former Secretary-General, Kofi Annan, said, the UN is not, a perfect organization but it is the best one we have. The necessity of the United Nations to reform both the basic principles and its own organizational structure derives from the radical change in the system of international relations.

Playing a very important role in the decision-making and representative mechanism of the organization, the nine secretaries-general so far have shared the critical attitude regarding the increased tendency of some states to bypass the UN, to avoid the involvement of this instrument of collective security in the concrete management of conflicts.

Concerns for the protection of human rights and victims of conflict are also part of the construction of the contemporary model of conflict resolution. A powerful tool is economic sanctions, with dramatic implications for any state trying to access global markets.

At the same time, encouraging of democratic governance in member countries can and must be a UN realistic and permanent mandate, especially since it exists clear support of most major contributors to the budget in this regard. The organization has the legitimacy and competence to contribute to the process of democratization on a global scale. The gradual elaboration of a relevant regulatory framework, as well as the assimilation and support of concrete action plans taken by Member States in various international forums, can crystallize a direction of reform, the possible key to other profound transformations.

However, the fate of the UN and, implicitly, of those mandated to lead the organization, is to express, defend and promote the building of a community of states and all the individuals that make them up globally.

The conceptual legitimacy of this desideratum is neither sufficiently supported by its level of institutionalization nor stronger in relation to that of the Member States, a vulnerability that can be overcome by the personality, competence, will and active involvement of the UN Secretary-General.

For example, the Secretary-General, with the agreement of the Security Council, shall bring to the attention of the General Assembly, at each session, all

4***, "We can end poverty", UN, URL: https://www.un.org/millenniumgoals/poverty.shtml, accessed on 25.07.2021.

$5 * * *$, "Levels and trends in child mortality" Report 2020, Estimates developed by the UN Interagency Group for Child Mortality Estimation. URL: https://www.unicef.org/media/79371/file/UNIGME-child-mortality-report-2020.pdf.pdf, accessed on 25.07.2021 
matters relating to the maintenance of international peace and security dealt with by the Security Council. Acts issued at the level of the General Assembly are resolutions and have the character of a recommendation for the member states without affecting their right to sovereignty ${ }^{6}$. Moreover, the Secretary General will act, in his capacity as the highest administrative official of the organization, at all meetings of the General Assembly, the Security Council, the Economic and Social Council and the Guardianship Council and may draw the attention of the Security Council on any issue which, in his opinion, could endanger the maintenance of international peace and security.

The UN also means projecting key values, such as universalism and individual diversity. Despite the inherent conceptual contradiction, the organization's dependence on the will of the Member States can also become a source of increasing the legitimacy of the $\mathrm{UN}$, insofar as states will consent to and recognize the validity of global objectives achievable only through intergovernmental organizations. Thus, a democratic legitimacy distinct from the national one, but complementary to it, will be sustained and nurtured.

\section{Initiatives of the Secretaries-General throughout UN's History}

The UN's Secretary-General is a symbol of the ideals of the United Nations and a spokesperson for the interests of the world's peoples. The UN' Charter defines him/her as "the highest-ranking official"', who performs in this capacity "all other functions with which he is entrusted" by the Security Council, the General Assembly, the Economic and Social Council and the Board of Trustees. The Charter authorizes the Secretary-General to "notify the Security Council of any file which, in his opinion, could endanger the maintenance of international peace and security". 9

Despite all these general specifications that define the duties of the office, the Secretary-General has considerable room for maneuver. He/she must also defend the values and moral authority of the United Nations and militate in his peace speeches and actions, even at the risk of sometimes contradicting the Member States, on whose support it depends very much. The Secretary-General, together with the entire Secretariat, has the prerogative not to show loyalty or obedience to any state, but only to the United Nations, his/her decisions being taken regardless of his/her country of origin.

One of his main roles is to use his integrity and influence on the one hand,

${ }^{6}$ According to art. 12 from UN Charter.

${ }^{7}$ A.N.: According to art. 97-99 from UN Charter.

${ }^{8}$ Ibidem.

${ }^{9}$ Ibidem. 
independence and impartiality on the other, to make his own efforts in public or in private in order to prevent the emergence, aggravation or spread of conflicts. ${ }^{10}$

We considered relevant the review of some of the most important initiatives and actions undertaken by the UN to respond to the challenges of the international security environment, which is constantly dynamic, but also the input of the secretaries-general to them, the way they identified ever new ways and solutions adapted to the new requirements as well as the way in which the projects were continued from one mandate to another.

Thus the first Secretary-General, Trygve Halvdan Lie, from Norway, was concerned, for the most part of his term (1946-1952), about the development of the Secretariat and the organization of the United Nations, headquartered in New York, in a competent structure. In addition, during this period a number of special organizations and humanitarian organizations were created, with the purpose of facilitating the reconstruction of territories destroyed during the war, especially at European level. A highlight of those years was the Universal Declaration of Human Rights, prepared by the UN Commission on Human Rights - a special body within the Economic and Social Council - and adopted unanimously on December 10, 1948, by the General Assembly. Due to the fact that the power of law was beginning to manifest itself, restricting the right to power as a result of the policies supported by the first UN Secretary-General, he becomes an awkward/uncomfortable person and various accusations are brought against him by some US senators related to the fact that it offered jobs in the organization to disloyal Americans. ${ }^{11}$

Since 1953, when after Stalin's death, relations between the two blocs have moved towards a state of relative relaxation, and within the UN there has been a relaxation of working conditions. 1953 is also the year when the Swede Dag Hammarskjöld was elected UN Secretary-General (the second secretary), being considered to this day the most efficient Secretary-General the Organization has ever $\operatorname{had}^{12}$. Dag Hammarskjöld was not only seen as a representative and administrative head of the United Nations. A man of initiative and vision, aware of the goals of the Organization, he skillfully used, in the years following his appointment, some niches in the UN' Charter to expand the Secretary-General's tasks and areas of activity.

\footnotetext{
${ }^{10}$ Ibidem.

$11 * * *$, "Norwegian statesman and secretary-general of the United Nations", Britannica, URL: https:// www.britannica.com/biography/Trygve-Lie, accessed on 13.05.2021.

${ }^{12}$ Dag Hammarskjoeld (Sweden) - Former Foreign Minister, he led the UN between 1953 and 1961. A great diplomat who mediated the Suez Canal crisis (1956) and the crisis in Jordan (1958), died in September 1961 in a mysterious plane crash during UN intervention in Belgian Congo (now the Democratic Republic of Congo) after its DC-6 plane crashed near Ndola (Zambia). URL: http://m. cotidianul.ro/mari-oameni-politici-disparuti-in-catastrofe-aeriene-112222/, and URL: http://evz. ro/moartea-unui-fost-sef-al-onu-cine-ar-fi-vrut-sa-il-elimine-pe-dag-hammarskjold- 942242. html?ref=newswire.ro_, accessed on 12.05.2021.
} 
Based on the 1950 Uniting-for Peace resolution, the United Nations developed, in the mid-1950s, at the request of the new Secretary-General, a completely new and unforeseen instrument of the Charter: "peacekeeping missions" ${ }^{13}$. Unlike classical forms of conflict resolution by confounding, these operations were not based on the use of force, serving to stabilize the principle of renunciation of violence, by installing a "buffer zone" between the parties to the conflict, under the strict condition of three principles: consensus of the parties to the conflict, impartiality of UN forces and use by UN forces of force strictly for self-defence or for the implementation of the entrusted mandate ${ }^{14}$.

Thanks to the United Nations, after the path to independence of the colonies had been marked in a first phase of bloody (liberation) struggles, this process could be diverted, on an orderly and peaceful path. The decolonization process also had substantial effects at the level of the United Nations. The newly independent states joined the Organization, so that the number of its members was enriched only between 1955 and 1962, with 50 new states. By 1965, 118 states were already part of the United Nations, and the geographical distribution of members had also changed fundamentally ${ }^{15}$. The former colonies that joined the UN were all, almost without exception, developing countries. These "third world" countries now had a majority in the General Assembly.

As a natural effect, the expansion of the organization through the accession of these states also led to the establishment of the premises for a UN Secretary General from underdeveloped or developing countries, former colonies of the great empires, as was the case of Sithu U Thant in Burma or Kofi Annan from Ghana. The two appointments have made a significant contribution to broadening the range of proactive UN human rights measures and bridging development gaps between countries around the world.

Thus, elected UN Secretary General in 1961, Sithu U Thant becomes the coordinator of new policies that have been at the center of the UN's attention, among which we distinguish Development Policy. Majority in the General Assembly, developing countries laid the foundations of UNCTAD (United Nations Congress on Trade and Development), the General Assembly proclaiming the "First Decade of Development"16. At the same time, in 1963, two amendments were made to the

\footnotetext{
$13 * * *$, United Nations Peacekeeping helps countries torn by conflict create conditions for lasting peace. URL: https://peacekeeping.un.org/en/what-is-peacekeeping and URL: https://peacekeeping. un.org/en/what-we-do, accessed on 12.05.2021.

${ }^{14}$ Ibidem.

15 United Nations, Member States, URL: https://www.un.org/en/member-states/, accessed on 12.05.2021.

$16 * * *$, UN Documentation: Development, URL: https://research.un.org/en/docs/dev/1960-1970 and https://undocs.org/en/A/RES/1710\%20(XVI), accessed on 13.05.2021.
} 
UN' Charter, so that the number of non-permanent members of the Security Council increased from six to ten, and the number of members of the Economic and Social Council increased from 18 to 27 (in 1971, once again, at 54).

In the early 1960s, when international peace was threatened and a huge danger posed to humanity by the "Cuban Missile Crisis" (October 16-28, 1962), the United Nations reported one of their most important achievements.

At the height of the confrontation, when a Soviet flotilla consisting of submarines with nuclear payloads on board and surface ships was already on its way to Cuba, whose maritime territory had been declared a quarantine zone for Soviet ships by US' President J.F. Kennedy, UN' Secretary-General Sithu U Thant has managed to stop the escalation of the conflict through direct mediation between the two conflicting parties.

Since 1972, Kurt Waldheim, from Austria, has been at the helm of the organization. At the heart of the United Nations' activities were several issues in various fields. Right from the inauguration of the new Secretary-General, was hosted the first world conference on the environment in Stockholm in June 1972, attended by delegations from more than a hundred nations and four hundred governmental and non-governmental organizations ${ }^{17}$, issues of great depth have been raised, which have now proved to be fundamental challenges for stability and peace in the world: the accelerated degradation of the environment, population growth and depletion of natural resources.

In this regard, we mention the adoption by the Extraordinary UN General Assembly in 1974, of the "Declaration on the Establishment of a New World Economic Order". It was supplemented by a "Charter of the Economic Rights and Obligations of States", adopted as a resolution, in December 1974, by the General Assembly. Although he had a shady past of adherence to the Nazi movement in World War II ${ }^{18}$, his diplomatic career after the end of the world conflagration, but also the position of representative of a neutral state in the confrontation of the two power blocs during the Cold War helped to focus on UN direction of action.

With regard to peacekeeping, the Organization was in a deep crisis in the 1980s, as in the previous decade: the UN continued to be present in the Middle East and in Cyprus with a number of missions, but they could not prevent new military confrontations in both areas of conflict. UN have been unable to intervene effectively in resolving the subsequent conflicts in Nicaragua, Western Sahara, Cambodia and Afghanistan, and in resolving the growing war between Iran and Iraq. The main problem was, at this stage of international policy, that the proposals

${ }^{17}$ Giancarlo Sturloni, Intoxicated planet, many words, few deeds, Seneca Publishing House, Bucharest, 2017, p. 23.

${ }^{18}$ Jonathan Kandell, Kurt Waldheim dies at 88; ex-UN chief hid Nazi past, URL: https://www.nytimes. com/2007/06/14/world/europe/14iht-waldheim.3.6141106.html, accessed on 13.05.2021. 
for a solution from the United Nations had not been heard ${ }^{19}$.

In this context, Pérez de Cuéllar, the fifth UN' Secretary-General, addressed the General Assembly in his 1983 annual report on a "process of decomposition of multilateralism and internationalism" 20 , which severely undermines the activities of the United Nations.

During his tenure as UN Secretary-General, Pérez de Cuéllar took part in several peace negotiations, including those between Britain and Argentina, during the Falkland Islands War - 1982, those between Israel and Lebanon, in during the Lebanon War - 1982, and those between Afghanistan and the Soviet Union, during the Soviet Invasion in Afghanistan - 1988. During the Iran-Iraq War, 1980-1988, Secretary-General Javier Pérez de Cuéllar personally negotiated a ceasefire end of active hostilities in August 1988.

This peacekeeping crisis has widened into an existential UN crisis due to Reagan's US policy of withdrawing and refusing to pay dues in the mid-1980s. This policy was triggered by US dissatisfaction with the unfavourable series of voting sessions in the General Assembly and the resolutions adopted by the Security Council, in which the US was forced to exercise its veto power to prevent the application. sanctions on South Africa and southern Rhodesia, as well as to stifle criticism of Israel's policy toward neighbouring states and the Palestinians.

The 90's brought new turmoil and conflicts on the global stage, manifestations that are other milestones for the UN. The missions in the former Yugoslavia, in Croatia, Bosnia-Herzegovina, Congo or Somalia have profoundly marked the evolution of UN' policies, causing new adaptations, but also reproaches to the UN.

The development of the "second generation" of the "peacekeeping" doctrine of the early 1990s have been rather gradual in nature, with missions taking place in post-conflict situations, ie in rather peaceful and peaceful contexts and starting from the premise of the existence of prior peace agreements, respectively of a consensus between the conflicting parties. However, some peacekeeping missions after 1992 have come into conflict with the fundamental principles of the Blue Helmets concept ${ }^{21}$.

Newly installed as UN' Secretary-General, Boutros Boutros-Ghali, has repeatedly argued that peacekeeping troops do not receive tasks that do not meet the principles and requirements specific to the concept of peacekeeping. An

\footnotetext{
19 United Nations peacekeeping, URL: https://peacekeeping.un.org/en/our-history, accessed on 13.05.2021.

${ }^{20}$ Edward Newman, The UN Secretary-General from the Cold War to the New Era, URL: https://link. springer.com/chapter/10.1057\%2F9780230504547_6.

21 Ion-Alexandru Groșeanu, NATO-EU-OSCE-UN comparative study on crisis management. (summary) Bucharest. URL: https://www.academia.edu/4657789/STUDIU_COMPARATIV_ NATO-UE-OSCE-ONU_privind_managementul_crizelor_rezumat_p. 9.
} 
eloquent example in this regard was the successive extension of the UNPROFOR mandate, carried out under the pressure of events and the determination of major actors, a determination that was not found in the military logistics provided. Blue Helmets soldiers were taken hostage several times, reaching positions between the fronts, which were often not even known to be composed of combat forces, regular armies or so-called warlords. The failed missions in Somalia and the former Yugoslavia symbolize the beginning of the UN' peacekeeping crisis $^{22}$.

In the reform measures implemented in the late 1990s, under the auspices of Boutros Boutros-Ghali, we distinguish the Secretariat's effort, as well as its subordinate departments, to adopt more drastic changes to align their competencies and capabilities with the challenges of that time ${ }^{23}$.

The seventh UN Secretary-General, Kofi Annan, begins his term in challenging times, with the international arena marked by numerous interethnic disputes in several regions of the world, and global environmental issues. Immediately after his appointment as Secretary-General, Kofi Annan took a reorientation of the Secretariat's work, defining four main goals for the United Nations, as follows: development; security; human rights; reforming the organization - as a ubiquitous $\operatorname{task}^{24}$. To these five areas, Kofi Annan subordinated to the various departments of the Secretariat and part of the special bodies and programs. In his report on reforms issued by the Heads of State and Government in 2000 at the UN' Summit, Kofi Annan identified three strategic objectives, which have since been an important point of reference in the reform debate, namely: Development Agenda (poverty release), Security Agenda (fear release) and Environmental Agenda (the future of ecology) ${ }^{25}$.

In his United Nations' reform program, presented in July 1997, the SecretaryGeneral Kofi Annan later generated the premises for a peaceful revolution. Under his leadership, the Millennium Summit allowed for collective commitments aimed at halving the level of poverty by $2015^{26}$.

\footnotetext{
${ }^{22}$ Sven Gareis, Johannes Varwick, "Die Vereinten Nationen. Aufgaben, Instrumente und Reformen; Bundeszentrale für politische Bildung Schriftenreihe Band 403", Bonn 2003 apud Military Science Magazine, no.1/2011, col. Ion Panait, "UN intervention in international conflicts", URL: http://www. aos.ro/wp-content/anale/RSMVol11Nr1(22)Art.6.pdf., accessed on 14.05.2021.

23 ***, UN Secretary General Boutros Boutros-Ghali and his contribution to Peacekeeping, URL: ppjournal.wordpress.com/2016/02/23/un-secretary-general-boutros-boutros-ghali-and-hiscontribution-to-peacekeeping/, accessed on 03.09.2021.

24 ***, "In Larger Freedom", The Report of the UN Secretary-General for the Millennium+5 Summit. URL: https://archive.globalpolicy.org/images/pdfs/briefing.pdf, accessed on 03.09.2021

${ }^{25}$ Secretary General Kofi Annan's Reform Agenda - 1997 to 2006, URL: https://www.globalpolicy. org/un-reform/32283-secretary-general-kofi-annans-reform-agenda-1997-to-2006.html, accessed on 14.05.2021.

${ }^{26}$ United Nations Millennium Declaration, Resolution adopted by the General Assembly, p. 4, URL: https://undocs.org/A/RES/55/2, accessed on 14.05.2021.
} 
In January 2007, Ban Ki-moon became UN Secretary-General, and was also elected for a second term, ending his term at the end of 2016. Ban Ki-moon faced a number of challenges, including Korean and Iranian nuclear threats, the Middle East and the humanitarian crisis in the Darfur region of Sudan. Being a skillful diplomat, (with experience gained in various positions in the MFA of South Korea), in April 2007, he managed to convince the Sudanese President, Omar al-Bashir, to allow peacekeepers to enter Sudan in order to resolve the interethnic conflict and resolve the humanitarian crisis. At the same time, in 2014, he managed, without much success, the international crisis caused by the forced annexation of Crimea by Russia.

Ban Ki-moon is responsible for major reforms in peacekeeping forces and UN' employment practices. He sought to strengthen UN peace efforts, including through the "The New Horizon" peacekeeping initiative. ${ }^{27}$

He was the promoter of the UN Women initiative and launched the "Unite to End Violence Against Women" ${ }^{28}$ campaign. During her tenure, the number of women in management positions in the organization increased by $40 \% \%^{29}$. Other priorities include mobilizing world leaders to meet a set of new global challenges, including major changes in climate change and economic crises, pandemics and rising pressures generated by food, energy and water shortages. But perhaps the most daring and comprehensive project in the history of the UN is the "2030 Agenda for Sustainable Development" that the international community has agreed to pursue.

The new UN Secretary-General, in office since January $1^{\text {st }}$, 2017, Antonio Manuel de Oliveira Guterres, takes over the leadership of the United Nations in a not so easy period. For some time (about 6 years), two major powers, the United States and Russia, have been in conflict over the most acute crisis in the world since the beginning of the $21^{\text {st }}$ Century - the situation in Syria. In addition, the international community is crushed by terrorism and is facing an unprecedented refugee crisis since World War II.

In his declaration, when he entered the race to become UN' SecretaryGeneral, Guterres drew attention to the fact that the world is facing increasing inequality and an intensification of terrorism, organized crime, climate change and

\footnotetext{
${ }^{27}$ A.N.: On 17 July 2009, the Department for Peacekeeping Operations (DPKO) and the Department of Field Support (DFS) launched a document entitled "A New Partnership Agenda: The Charter for the United Nations New Horizon for Peacekeeping", The New Horizon Initiative: Progress Report No.1, October 2010, Department of Peacekeeping Operations and Department of Field Support, New York, URL: https://peacekeeping.un.org/sites/default/files/newhorizon_update01_0.pdf, accessed 14.05.2021.

$28 * * *$, "Ban Ki-moon", The Elders, URL: https://www.theelders.org/profile/ban-ki-moon, accessed on 14.05.2021.

${ }^{29}$ Ibidem.
} 
the proliferation of weapons. He stressed that the UN "is in a unique position to unite the points to overcome these challenges", but change and reform are needed ${ }^{30}$. Without mentioning any particular conflict, the Portuguese diplomat called for a ceasefire on the "battlefields" to move on to negotiations aimed at "political solutions". The new UN Secretary-General asked what the international community can do to help the millions of people living "caught up in wars that don't seem to end." "No one emerges victorious from these wars, they all lose", lamented Guterres, who specifically denounced the impact on the civilian population. "Let's make 2017 a year of peace" 31 , Antonio Guterres concluded on the first day of his term as Secretary-General.

Antonio Guterres is highly appreciated at the UN and has a reputation of a good speaker and a fierce advocate of human rights. He also repeatedly pressured strong countries to do more to help the vulnerable.

Since the beginning of his term in January 2017, UN Secretary-General António Guterres has made proposals to reform the United Nations. To improve the delivery of the organization mandate, the United Nations has made sweeping changes in development, management and peace and security ${ }^{32}$.

In the development area, the 2030 Agenda required bold changes to the UN development system for the emergence of a new generation of country teams, centered on a strategic UN Development Assistance Framework and led by an impartial, independent and empowered resident coordinator.

Regarding the management area, a new management paradigm for the Secretariat and a United Nations that empowers managers and staff, simplifies processes, increases transparency and improves on the delivery of UN mandates was necessary.

For the peace and security area, the overarching goals of the reform were to prioritize prevention and sustaining peace; enhance the effectiveness and coherence of peacekeeping operations and special political missions and move towards a single, integrated peace and security pillar.

"With the structural aspects of the reforms now well consolidated, it is imperative to keep the foot in the pedal to achieve the cultural change we need for greater collaboration across pillars and tangible results for people on the ground" ${ }^{\prime 3}$, the UN

\footnotetext{
${ }^{30}$ Viorica Marin, Ifonografie Antonio Guteress, noul șef al ONU, 13.10.2016. URL: https://adevarul. ro/international/in-lume/antonio-guterres-noul-sef-onu-1_57ffa4085ab6550cb88738a3/index.html, accessed on 03.09.2021.

$31 * * *$, "Noul secretar general al ONU, António Guterres, şi-a început mandatul cu un apel pentru pace", Agerpres, 01.01.2017. URL: https://www.agerpres.ro/externe/2017/01/01/noul-secretargeneral-al-onu-ant-nio-guterres-si-a-inceput-mandatul-cu-un-apel-pentru-pace-08-26-48, accessed 03.09.2021.

32 ***, United to Reform, URL: https://reform.un.org/, accessed on 25.07.2021.

${ }^{33}$ Ibidem.
} 
Secretary-General, António Guterres, declared.

In 2019, UN Secretary-General António Guterres announced the official launch of sweeping reforms to the United Nations which promise to focus on "people rather than progress, effectiveness and adaptability, and on equality, diversity and integrity" 34 .

Regarding the reform program, his Excellency persevered and delivered" seven major changes:

- A system-wide strategic document to accelerate the alignment of the UN development system with the 2030 Agenda and serve as a method of accountability.

- A new generation of UN Country Teams (UNCTs), with the expertise to support the advancement of the SDGs, working together with local actors.

- A Resident Coordinator (RC) with greater authority to make final strategic development decisions as well as defining which agencies will lead responses to humanitarian crises.

- A strengthened Department of Economic and Social Affairs (DESA) through its inclusion in the Regional Coordination Mechanism (RCM).

- Improved strategic guidance, transparency and accountability by implementing the ECOSOC Operational Activities Segment (OAS) as an accountability system for the 2030 Agenda.

- A system-wide approach to partnerships, including the launch of six partnership-related work streams.

- A new Funding Compact between Member States and the UN development system that would enhance transparency of financial data." ${ }^{35}$

In the new pandemic context, on 19 March 2020, the Secretary-General declared that „We are facing a global health crisis unlike any other in the 75-year history of the United Nations - one that is spreading human suffering, infecting the global economy and upending people's lives" ${ }^{36}$.

He called for action in three critical areas: (i) tackling the health emergency, (ii) focus on the social impact and the economic response and recovery, and (iii) having a responsibility to "recover better" 37 .

During the UN General Assambly plenary meeting held on 28-29 January 2021, in New York, USA, the Secretary-General explained how the 2030 Agenda points

\footnotetext{
${ }^{34}$ Michael Nguyen, “Guterres' UN reforms: necessary, modest, and progressing”, February, 2019, URL: https://devpolicy.org/guterres-un-reforms-necessary-modest-and-progressing-20190226/, accessed on 25.07.2021.

${ }^{35}$ Ibidem.

$36 * * *$, "Secretary-General virtual press encounter on COVID-19 CRISIS", 19 March 2020. URL: https://www.un.org/sg/en/content/sg/press-encounter/2020-03-19/secretary-general-virtual-pressencounter-covid-19-crisis, accessed on 25.07.2021.

${ }^{37}$ Ibidem.
} 
the way to a sustainable and inclusive recovery from COVID-19, how humans can "make peace with nature", and a strategy for increasing women's rights ${ }^{38}$.

At the meeting, Antonio Guterres presented the Ten Priorities for 2021, as follows:

1. an effective response to the COVID-19 pandemic;

2. start an inclusive and sustainable economic recovery;

3. make peace with nature;

4. tackle poverty and inequality;

5. reverse the assault on human rights;

6. gender equality, the greatest human rights challenge;

7. heal geopolitical rifts;

8. reverse the erosion of the nuclear disarmament and non-proliferation regime;

9. seize the opportunities of digital technologies while protecting against their growing dangers;

10. launch a reset for the $21^{\text {st }}$ century.

At the meeting at the beginning of the year, the Secretary-General recommended that the vaccine for the prevention of COVID-19 be available and accessible to all, and to distribute it as a priority to the most vulnerable population groups.

At the same time, the Secretary-General called on states to declare national climate emergencies; make nationally determined contributions (NDCs) to reducing emissions; phasing out fossil fuels; increasing support for adaptation; to help build the coalition for a carbon-neutral world - which means that every country, city, companies and financial institutions has a clear path to carbon neutrality by 2050 .

With regard to combating poverty and inequality, the Secretary-General described a new social contract supported by digital education and technology.

On gender equality and respect for human rights, the Secretary-General stressed that women, girls, minorities and LGBTQ people face chronic discrimination and violence, and the COVID-19 pandemic has exacerbated the growing threat to human rights around the world.

\section{Conclusions}

Highlighting the activities and actions of the UN Secretaries-General during their terms of office leads us to the conclusion that their role has been and continues to be extremely important in achieving the purpose and objectives of the organization, in developing policies that address the challenges of global security.

38 *** "UN Secretary-General Presents 10 Priorities for 2021, 3 February 2021”, URL: https:// sdg.iisd.org/news/un-secretary-general-presents-10-priorities-for-2021/, accessed on 26.07.2021. 
The analysis demonstrates the impact that the qualities and the active involvement of the Secretary General in the measures taken at the UN level can have, both for the structural reform of the organization and for the fulfillment of its functional role.

The tasks facing the UN in the future are difficult and numerous. Beyond what state or non-state actors can stage, new crises or conflicts, the organization must channel its efforts to achieve the 17 global objectives and 169 targets on the 2030 Agenda, a project for the future adopted in 2015 by the international community.

The large but also difficult project that aims to create a better world is the "maturity exam" that must now be passed by humanity so that the future of the planet does not become uncertain and man, from the subject of history, does not become its object.

The current UN Secretary-General's mission is a difficul and challenging one. The achievement of the great goals of the 2030 Agenda depends on its organizing capacity and diplomatic ability to mobilize world governments, NGOs and other bodies, through a global coalition and sustained effort.

\section{BIBLIOGRAPHY:}

1. ***, "Lessons from the UN peacekiping mission in Rwanda. 25 years after the genocid it failes to stop", The Conversation, September 5, 2019, URL: https:// theconversation.com/lessons-from-the-un-peacekeeping-mission-in-rwanda-25years-after-the-genocide-it-failed-to-stop-122174

2. ***, "Noul secretar general al ONU, António Guterres, şi-a început mandatul cu un apel pentru pace", Agerpres, 01.01.2017. URL: https:/www.agerpres.ro/ externe/2017/01/01/noul-secretar-general-al-onu-ant-nio-guterres-si-a-inceputmandatul-cu-un-apel-pentru-pace-08-26-48

3. ***, Global governance and global rules for development in the post-2015 era, United Nations, June 2014, URL: https://www.un.org/development/desa/dpad/ publication/cdp-policy-note-2014/

4. ***, Infografie Antonio Gutteres, noul șef al ONU, 13 October 2016, URL: https://adevarul.ro/international/in-lume/antonio-guterres-noul-sef-onu1_57ffa4085ab6550cb88738a3/index.html

5. ***, Levels and trends in child mortality, Report 2020, Estimates developed by the UN Inter-agency Group for Child Mortality Estimation. URL: https://www. unicef.org/media/79371/file/UN-IGME-child-mortality-report-2020.pdf.pdf

6. ***, Secretary-General virtual press encounter on COVID-19 CRISIS, 19 March 2020, URL: https://www.un.org/sg/en/content/sg/press-encounter/2020-0319/secretary-general-virtual-press-encounter-covid-19-crisis 
7. ***, The Charter of the United Nations, San Francisco, 1945 URL: http:// legislatie.just.ro/Public/DetaliiDocumentAfis/19362

8. ***, The Future is Now: Science for Achieving Sustainable Development, is the first quadrennial Global Sustainable Development Report prepared by an independent group of scientists, United Nations, 2019, URL: https://sustainabledevelopment.un.org/content/ documents/24797GSDR_report_2019.pdf

9. ***, The Global Risks, Report 2020, 15th Edition, World Economic Forum Global Risks, in partnership with Marsh \& McLennan and Zurich Insurance Group, 2019-2020, URL: https://www.un.org/development/desa/dpad/publication/cdppolicy-note-2014/

10. ***, The Millennium Project. Global futures studies \& research, URL: http://www.millennium-project.org/rtd-general

11. ***, Transforming our world: the 2030 Agenda for Sustainable Development, UN, New York, 2015, URL: https://www.un.org/ga/search/view_doc. asp?symbol $=\mathrm{A} / \mathrm{RES} / 70 / 1 \&$ Lang $=\mathrm{E}$

12. ***, Trygve Lie. Norwegian statesman and secretary-general of the United Nations, URL: https://www.britannica.com/biography/Trygve-Lie

13. ***, UN official website, URL: https://www.un.org/en/

14. ***, UNESCO moving forward the 2030 Agenda for Sustainable Development, UNESCO, 2017, URL: https://en.unesco.org/creativity/files/unescomoving-forward-2030-agenda-sustainable

15. ***, United to Reform, URL: https://reform.un.org/

16. ***, We can end poverty. Millenium development goals and beyond 2015, URL: https://www.un.org/millenniumgoals/poverty.shtml

17. BOIN, Arjen; HART, Paul't; STERN, Eric; SUNDELIUS, Bengt, The Politics of Crisis Management, Cambridge Univeristy Press, New York, 2005.

18. BUȚA, Viorel, "Evoluția conceptului strategic al NATO", URL: http:// www.aos.ro/wp-content/anale/RSMVol11Nr1(22)Art.6.pdf

19. CHIRIAC, Mircea-Dănuţ, Security policies and strategies at the beginning of $21^{\text {st }}$ Century, „Carol I” National Defense University Publishing House, Bucharest, 2005.

20. CHIRIAC, Mircea-Dănuţ; DUMITRU, Daniel; ION, Emil, Political and security organizations and institutions, „Carol I” National Defense University Publishing House, Bucharest, 2007.

21. DUMITRIU, Petru, The UN system in the context of glogalization: reform as will and representation, Curtea Veche Publishing House, Bucharest, 2008.

22. Edward Newman, "The UN Secretary-General from the Cold War to the New Era", URL: https://link.springer.com/chapter/10.1057\%2F9780230504547_6

23. GAREIS, Sven; VARWICK, Johannes, Die Vereinten Nationen. Aufgaben, Instrumente und Reformen; Bundeszentrale für politische Bildung Schriftenreihe Band 403, Bonn 2003. 
24. KANDELL, Jonathan, "Kurt Waldheim dies at 88; ex-UN chief hid Nazi past.", URL: https://www.nytimes.com/2007/06/14/world/europe/14cnd-waldheim. html.

25. KAPUR, Davesh, Processes of Change in Internațional Organizations, 2010, URL: https://wcfia.harvard.edu/files/wcfia/files/164_helsinki3.wcfia_pdf

26. KONRAD, Lorenz, Civilized Man's Eght Deadly Sins, Humanitas Publishing House, Bucharest, 2012.

27. LESTER, Brown R., Plan B 4.0, Mobilizing to Save Civilization, Earth Policy Institute, New York, London, 2008.

28. NGUYEN, Michael, "Guterres' UN reforms: necessary, modest, and progressing", February, 2019, URL: https://devpolicy.org/guterres-un-reformsnecessary-modest-and-progressing-20190226/

29. PANAIT, Ion, "Intervenția ONU în conflictele internaționale", Revista de științe militare, nr. 1/2011, URL: http://www.aos.ro/wp-content/anale/ RSMVol11Nr1(22)Art.6.pdf

30. STURLONI, Giancarlo, Intoxicated planet, many words, few deeds, Seneca Publishing House, Bucharest, 2017. 